E-ISSN: 2808-5361

http://e-journal.fkmumj.ac.id/
Proceeding The First

Muhammadiyah Internasional-

Public Health and Medicine

Conference

\title{
Analysis of Factors Related to Patient Loyalty During The Covid-19 Pandemic at The Ciasmara Health Center in 2021
}

\author{
Diah Setyawati \\ Faculty of Public Health, Muhammadiyah University of Jakarta \\ K.H. Ahmad Dahlan Street,Cireundeu, Ciputat, South Jakarta, 15419 \\ Email: diah.wati12@gmail.com
}

\begin{abstract}
Since the Covid-19 pandemic occurred in March 2020 in Indonesia, many aspects of life have been affected, including health care facilities. This condition has changed people's lifestyles, community visits to health care facilities have decreased. Public interest in visiting public health service facilities has also decreased. One of the public health facilities that feel the impact is the Public Health Center. The purpose of this study was to determine the factors - factors associated with patient loyalty at the Public Health Center. This type of research is quantitative analytic with a cross-sectional approach, the types of statistical tests used are the Chi-square test and Logistic Regression test. The location of the research was at the Ciasmara Health Center, the time of the study was from January to July 2021. The number of samples was 120 respondents, the sampling technique was total sampling. The results of the univariate analysis showed that most of the respondents were not loyal to Public Health Center services, namely $51.7 \%$. The results of the chi-square test showed that of the 7 independent variables studied, only 3 variables were significant on patient loyalty ( $p$-value < 0.05), namely: attitude (0.021), service quality (0.034), and employee performance (0.024). While the variables of knowledge, economic level, distance from the house, and infrastructure are not significant because the p-value > 0.05. The results of the logistic regression test showed that the most dominant factor related to patient loyalty was employee performance. The quality of service and employee performance at the Public Health Center needs to be improved as long as it is through improving services and providing rewards and punishments for employees who perform well and poorly. Next, the patient's attitude needs to be improved through education and counseling carried out by the Public Health Center.
\end{abstract}

Keywords: Patient loyalty, Pandemic, Covid-19 


\section{INTRODUCTION}

Since the Covid-19 outbreak occurred in March 2020 in Indonesia, many aspects of life have been affected, including health care facilities. The prevalence of Covid-19 is increasing all the time, the WHO report states that cases ofCovid-19 are increasing every day, the number of Covid-19 cases in various countries is 73.4 million cases, and there are1.63 million cases of death fromCovid-19 worldwide. Furthermore, transmission in various regions in Indonesia also continues to increase. Kusnyacontinues to grow to 632,000 cases throughout Indonesia and spread in 34 provinces with 282 districts/cities affected and the death rate reaches 18,956 cases (Ministry of Health, 2020).

The presence ofCovid-19 has changed people's lifestyles, community visits to health care facilities have decreased. Public interest in visiting public health care facilities has also decreased. One of the public health facilities that feel the impact is the Public Health Center.

Health care services are closely related to the quality of basic services, so it is contained that Public Health Center is obliged to maintain and even improve the quality of basic public health services. On the basic quality of public health, namely by providing quality of service that satisfies visitors who come (patients) or by providing conformity with established service standards and can also reach all levels of society. As a health care unit, of course, it must be able to provide positive values for the creation of a trust to be able to provide patients who are loyal to the services provided by the Health Center. In addition to the optimal quality of service, the location must also be easily reached with access that facilitates patients or visitors who come to the Health Center to create loyal patients.

Public Health Center itself can indeed be said to be cheap and easy to reach health service, but if the Health Center is not able to provide excellent and optimal stewardship then there will be no patient who is loyal to the service so as not to provide a sense of satisfaction, this is certainly a demand where the Public Health Center itself must further improve the quality of its services. The importance of quality of service certainly aims to meet the needs or desires that in the hopes of providing satisfaction value to provide a value of trust to the patient. The good quality of service provided depends on the lack of optimal service, comfort, speed in serving patients. But the quality of good service is not enough if only achieved but must be maintained and maintained. Because the fulfillment of the quality of service will certainly create trust in patient loyalty (Banan, 2020).

West Java is one of the provinces with the largest area and the largest population on Java Island. Various health issues are also still the duty of leaders in the region, including the quality of health services in every health care facility. One of the largest and most populated regencies in West Java Province in Bogor Regency, there are still many health problems that become in this region, including the quality of services in health centers. Patient loyalty to the health care institution in wilayah also experienced a significant decline. Bogor Health Office report, that since the occurrence of the Covid-19 pandemic occurred in West Java, patient visits at health centers have decreased 
between $30.0 \%-60.0 \%$. Even a report from the Ministry of Health shows that JKN visits (national health insurance) decreased drastically to 70.69 million people, in 2019, the number of JKN service visits in health facilities was 433.39 million. Then during the Covid-19 pandemic in 2020 to 362.7 million (Pebrianto, 2021).

Researchers then made observations at one of the Health Centers, namely Public Health Center Ciasmara. Public Health Center Ciasmara is one of the branches of health services in Bogor Regency. Quality of service and trust is certainly the main key to increasing loyalty to patients in this health center. With the number of patients increasing every month, of course, the services provided must be optimal and also by the SOP, this can have a positive impact both to the patient and on the diamond. The progress of the times, of course, is the main focus so that Ciasmara Health Center patients trust and are satisfied with the services provided to visiting patients.

During the Covid-19 pandemic that occurred in early March 2020, the number of patient visits at Ciasmara Health Center decreased by more than30.0\% (1,421 patients), with a comparison in 2019 amounting to 2,030 patients, especially patients who had diabetes mellitus, tuberculosis, stroke, heart disease, hypertension, Those who have to get regular care also experience a decrease in visits. This condition certainly gets the attention of the manager of the Public Health Center. Based on this situation, researchers try to identify some things that may be the cause of this decrease in visits. Furthermore, researchers conducted a preliminary study of several health center managers and 10 patients through interview methods to find out about patient visits, getting some information that there could be a decrease in visits could occur due to Iranian patient concerns to Covid-19 transmissions, such as mini-knowledge and patient attitude towards Covid-19 transmission. In addition, other things are suspected to affect, namely: the quality of service, the performance of officers, infrastructure facilities in the health center, the distance of the patient's home, and the economic status of the patient.

Based on this situation, researchers feel the need for scientific studies to find out more about patient loyalty and its causative factors to be scientifically identified and found out solutions to solve the problem. The purpose of this study is to find out the factors related to patient loyalty at the Ciasmara Health Center in 2021.

\section{METHODS}

This research activity was conducted at Ciasmara Kabupaten Bogor Health Center. Research factors are limited to patient factors (knowledge, attitude, economic level, distance of home) and institution factors (quality of service, employee performance, infrastructure facilities). Types of analytical quantitative research with a Cross-sectional approach, the types of statistical tests used are the Chi-square test and the Logistic Regression test. The research site was conducted at Ciasmara Health Center during January - July 2021. The subjects in the study were all degenerative disease 
patients who sought treatment at Ciasmara Health Center as many as \pm 120 patients in January to April 2021, the number of samples using the total sampling technique.

\section{RESULTS AND DISCUSSIONS}

Table 1. Research Variable Frequency Distribution

\begin{tabular}{cllrr}
\hline Number & \multicolumn{1}{c}{ Variable } & \multicolumn{1}{c}{ Category } & Total & Percentage \\
\hline 1. & Patient loyalties & Disloyal & 62 & 51.7 \\
2. Knowledge & Loyal & Less & 58 & 48.3 \\
& & Good & 30 & 25.0 \\
3. Attitude & Negative & 90 & 75.0 \\
& & Positive & 44 & 36.7 \\
4. Economic level & <UMR & GUMR & 76 & 63.3 \\
& & Far & 88 & 73.3 \\
5. Home distance & Near & Les & 32 & 26.7 \\
& & Quality & 34 & 28.3 \\
6. Service quality & Less & 86 & 71.7 \\
& & Good & 56 & 46.7 \\
7. Performance & Inadequate & 64 & 53.3 \\
8. Infrastructure facilities & Adequate & 62 & 51.7 \\
& & 58 & 48.3 \\
& & 40 & 33.3 \\
& & 80 & 66.7 \\
\hline
\end{tabular}

Source: Research Variable Frequency Distribution

Based on table 1 on the distribution of respondents' frequency according to research variables (patient loyalty, knowledge, attitude, economic level, home distance, service quality, performance, and infrastructure facilities), it can be explained as follows: in the variable dependent patient loyalty to services in the Covid-19 pandemic obtained data that from 120 respondents interviewed found the percentage among disloyal and loyal respondents almost evenly, $51.7 \%$ were less loyal and $48.3 \%$ loyal. The measuring yield ratio in each variable is relatively evenly distributed for all variables.

Table 2. Independent and Dependent Variable Relationship

\begin{tabular}{|c|c|c|c|c|c|c|}
\hline \multirow{3}{*}{ Variable } & \multirow{3}{*}{ Category } & \multicolumn{2}{|c|}{ Patient loyalties } & \multirow{2}{*}{ Total } & \multirow{3}{*}{$P$ value } & \multirow{3}{*}{$\begin{array}{c}\text { OR } \\
(95 \% C I)\end{array}$} \\
\hline & & Disloyal & Loyal & & & \\
\hline & & n (\%) & n (\%) & $\mathbf{N}(\%)$ & & \\
\hline \multirow[t]{2}{*}{ Knowledge } & Less & $15(50,0)$ & $15(50,0)$ & $30(100,0)$ & \multirow{3}{*}{0,596} & \multirow{3}{*}{$\begin{array}{c}1,368 \\
(0,5-3,1)\end{array}$} \\
\hline & Good & $38(42,2)$ & $52(57,8)$ & $90(100,0)$ & & \\
\hline \multicolumn{2}{|c|}{ Total } & $53(44,2)$ & $67(55,8)$ & $120(100,0)$ & & \\
\hline \multirow[t]{2}{*}{ Attitude } & Negative & $26(59,1)$ & $18(40,9)$ & $44(100,0)$ & \multirow{3}{*}{0,021} & \multirow{3}{*}{$\begin{array}{c}2,621 \\
(1,2-5,6)\end{array}$} \\
\hline & Positive & $27(35,5)$ & $49(64,5)$ & $76(100,0)$ & & \\
\hline \multicolumn{2}{|c|}{ Total } & $53(44,2)$ & $67(55,8)$ & $120(100,0)$ & & \\
\hline \multirow{2}{*}{$\begin{array}{c}\text { Economic } \\
\text { level }\end{array}$} & $<$ UMR & $38(43,2)$ & $50(56,8)$ & $88(100,0)$ & \multirow{3}{*}{0,879} & \multirow{3}{*}{$\begin{array}{c}0,861 \\
(0,3-1,9))\end{array}$} \\
\hline & $\geq \mathrm{UMR}$ & $15(46,9)$ & $17(53,1)$ & $32(100,0)$ & & \\
\hline \multicolumn{2}{|c|}{ Total } & $53(44,2)$ & $67(55,8)$ & $120(100,0)$ & & \\
\hline Home & Far & $15(44,1)$ & $19(55,9)$ & $34(100,0)$ & \multirow{3}{*}{1,0} & \multirow{3}{*}{$\begin{array}{c}0,997 \\
(0,4-2,2)\end{array}$} \\
\hline distance & Near & $38(44,2)$ & $48(55,8)$ & $86(100,0)$ & & \\
\hline \multicolumn{2}{|c|}{ Total } & $53(44,2)$ & $67(55,8)$ & $120(100,0)$ & & \\
\hline
\end{tabular}




\begin{tabular}{|c|c|c|c|c|c|c|}
\hline Variable & Category & \multicolumn{2}{|c|}{ Patient loyalties } & Total & $P$ value & OR \\
\hline \multirow{2}{*}{$\begin{array}{l}\text { Service } \\
\text { quality }\end{array}$} & Less & $31(55,4)$ & $25(44,6)$ & $56(100,0)$ & \multirow{3}{*}{0,034} & \multirow{3}{*}{$\begin{array}{c}2,367 \\
(1,1-4,9)\end{array}$} \\
\hline & Good & $22(34,4)$ & $42(65,6)$ & $64(100,0)$ & & \\
\hline \multicolumn{2}{|c|}{ Total } & $53(44,2)$ & $67(55,8)$ & $120(100,0)$ & & \\
\hline \multirow{2}{*}{ Performance } & Less & $34(54,8)$ & $28(45,2)$ & $62(100,0)$ & \multirow{3}{*}{0,024} & \multirow{3}{*}{$\begin{array}{c}2,492 \\
(1,1-5,2)\end{array}$} \\
\hline & Good & $19(32,8)$ & $39(67,2)$ & $58(100,0)$ & & \\
\hline \multicolumn{2}{|c|}{ Total } & $53(44,2)$ & $67(55,8)$ & $120(100,0)$ & & \\
\hline \multirow[t]{3}{*}{ Facilities } & Inadequate & $21(52,5)$ & $19(47,5)$ & $40(100,0)$ & \multirow{3}{*}{0,269} & \multirow{3}{*}{$\begin{array}{c}1,658 \\
(0,7-3,5)\end{array}$} \\
\hline & Adequate & $32(40,0)$ & $48(60,0)$ & $80(100,0)$ & & \\
\hline & & $53(44,2)$ & $67(55,8)$ & $120(100,0)$ & & \\
\hline
\end{tabular}

Source: Research Variable Frequency Distribution

The results of the chi-square test obtained data that from 7 independent variables studied, only 3 variables were significant to patient loyalty ( $p$-value < 0.05 ), namely: attitude $(0.021)$, service quality (0.034), and employee performance (0.024). While the variables of knowledge, economic level, the distance of houses and infrastructure facilities are not significant because of the value of $p$ > 0.05 .

The results of this study are not in line with the research of Nondyawati A.Kiky (2015) that knowledge and attitudes affect the interests of patient recovery. Asif M (2019) posits that patient knowledge influences his behavior in utilizing health services. This is reinforced in Linda H Aiken's research, 1 Douglas M Sloane, et.al (2018) that patients' perceptions of care are significantly eroded by a lack of trust in either nurses or doctors. Furthermore, Ramli A. Haeba 's research (2016) also suggested that patients who know the quality of service of a hospital will be more loyal to using services at the hospital. Selim Ahmed, Kazi Md. Tarique, Ishtiaque Arif (2017) suggests that there is a relationship between quality of service and patient satisfaction with patient loyalty.

The results of this study are in line with the research of Nondyawati A.Kiky (2015) that knowledge and attitudes affect the interests of patient recovery. Furthermore, in the study Dachyar, M., Farizal, \& Minar, I. P. (2018) also suggested that patient attitudes can affect the behavior of health care utilization. Patients will be healthy health services when their attitude is positive towards the needs of health services. The patient's attitude is usually determined by previous knowledge and experience, the experience before the positive will make the patient want to do it again, vice versa. Therefore, the level of patient satisfaction during the service is noteworthy. Patient satisfaction becomes important in encouraging patients to be willing to reuse health care facilities, if the more satisfied the patient will be more loyal. As in Yudhawati N Putu's research (2019) that the quality of nurse services affects patient loyalty ( $p$-value: 0.000 ), patient satisfaction also affects patient loyalty (p-value: 0.000).

The patient's perception will determine his attitude in assessing services in a health care facility. The patient's perception of the service plays a very important role. The quality of service will be fulfilled if the process of delivering services from the service provider to the patient is by what is 
perceived by the patient. Welch further stated in Kotler (2012) stated that the quality of service is the best guarantee to create and maintain consumer loyalty and bulwark in the face of global competition.

The results of this study are not in line with research conducted by Dachyar, M., Farizal, \& Minar, I. P. (2018) which argues that a patient's loyalty to a product/health service is influenced by its economic ability, the higher its economic ability, the higher the patient's interest in buying the desired product/service.

The results of this study are not in line with research conducted by Keshavarz, Yousef, Jamshidi, Dariyoush, and Bakhtazma, Farid (2016) which suggested that a person's behavior in utilizing health services is determined by the distance of the home to health facilities.

The results are in line with research conducted by Buchari Imam Bachari Kamal. Mella Sari (2018) that the quality of service affects patient loyalty, the better the quality of service, the more loyal the patient is in utilizing health services. Further, Palit, Kristanti, Aysia, and Priscilla (2016) also revealed that the quality of service has a statistical effect on patient loyalty (p-value < 0.05 ), and Pushkar Dubey's research, Satish Kumar Sahu (2019) also said that the quality of service affects patient loyalty.

The results of this study are in line with research conducted by Palit, Kristanti, Aysia, and Priscilla (2016) which revealed that a patient will be loyal to the health service if the service performance of health workers is good. Furthermore, Setiawan, Heri, and Sayuti (2017) research also revealed that there is a significant relationship between performance and patient loyalty.

Public Health Center as a health service provider facility should prepare qualified human resources. HUMAN RESOURCES is the main key factor in the success of development to create a quality human being that required a degree of excellent human health so that, in this case, necessary optimal, comprehensive, and equitable health development. To support the creation of a health development achievement, the government's efforts have provided some health facilities and facilities and experts in the field of health.

The results of this study are not in line with research conducted by Selim Ahmed, Kazi Md. Tarique, Ishtiaque Arif (2017) Bangladesh which successfully revealed the correlation between infrastructure facilities and customer loyalty, adequate and complete facilities can improve customer satisfaction and will further give a good image to service facilities and encourage customers to return to using the services/products sold.

Infrastructure facilities in a complete and well-functioning health center will further improve the quality of service. The quality of services is always based on efforts to eliminate the gap between the desired (expected) and the situation faced (perceived).

Table 3. Multivariate Modeling I

\begin{tabular}{lrlrl}
\hline Variable & \multicolumn{4}{c}{ P value } \\
\cline { 2 - 4 } & Model I & OR & Model Terakhir & OR \\
\hline
\end{tabular}




\begin{tabular}{lllll}
\hline Attitude & 0,034 & 2,373 & 0,034 & 2,373 \\
Service Quality & 0,028 & 2,388 & 0,028 & 2,388 \\
Performance & 0,024 & 2,454 & 0,024 & 2,454 \\
\hline
\end{tabular}

Source: Research Variable Frequency Distribution

Based on table 5.6 on multivariate modeling, it is obtained that variables related to patient loyalty in the health center during the pandemic period are: attitude, quality of service, and employee performance. Of the three variables, there is one variable that is most dominantly related to patient loyalty in undergoing treatment, because it has the lowest $p$-value and the highest $\mathrm{OR}$ is the employee performance variable $(\mathrm{p}$-value $=0.024)$. The modeling results obtained Odds Ratio $(\mathrm{OR})$ from the Motivation variable is 2,454 , meaning that respondents who stated that employee performance was less likely to be 2 times more disloyal to the service at the health center compared to respondents who stated good employee performance. Thus, it can be concluded that the most dominant variable that has a significant effect on employee loyalty is employee performance after being controlled by service quality and attitude variables.

The results of this study are in line with research conducted by Taqdees Fatima, Shahab Alam Malik, Asma Shabbir (2018) that customers will be satisfied if the good performance and Dampanya are the customers is increasingly loyal to buy the products sold. Furthermore, titin Lestariningsih, Ernani Hadiyati, Rini Astuti. (2018) also showed that there is a significant relationship between performance and loyalty. In Wolter research, J. S., Bock, D., Smith, J. S., \& Cronin, J. J. (2017) also suggested that customers tend to make repeated purchases if the work performance of employees is good.

\section{CONCLUSIONS AND SUGGESTIONS}

Since the beginning of 2020 many hospitals and health care institutions in Indonesia have experienced a decrease in the number of patient visits. Patient loyalty to services in health facilities in Indonesia decreased significantly as a result of the global pandemic.

During the Covid-19 pandemic that occurred in early March 2020, the number of patient visits at Ciasmara Health Center decreased significantly to more than $30.0 \%$ (1,421 patients), with a comparison in 2019 amounting to 2,030 patients.

Based on previous data, there was a decrease in the number of patient visits at Ciasmara Health Center, researchers analyzed factors that affect patient loyalty relationships during the Covid19 pandemic at Ciasmara Health Center.

Based on the results of the study and discussion in the previous section, the researcher concluded several things, as follows:

1. There is no relationship between knowledge and patient loyalty at Ciasmara Health Center.

2. There is a significant relationship between attitude and patient loyalty at Ciasmara Health Center.

3. There is no relationship between economic level and patient loyalty at Ciasmara HealthCenter. 
E-ISSN: 2808-5361

http://e-journal.fkmumj.ac.id/
Proceeding The First Muhammadiyah InternasionalPublic Health and Medicine Conference

4. There is no relationship between home distance and patient loyalty at Ciasmara Health Center.

5. There is a significant relationship between the quality of service and patient loyalty at Ciasmara Health Center.

6. There is a significant relationship between employee performance and patient loyalty at Ciasmara Health Center.

7. There is no relationship between infrastructure advice and patient loyalty at Ciasmara Health Center.

In multivariate modeling, it is obtained that variables related to patient loyalty in the health center during the pandemic period are: attitude, quality of service, and employee performance. Of the three variables, there is one variable that is most dominantly related to patient loyalty in undergoing treatment, namely employee performance variables, where employee performance variables are less likely to be 2 times more loyal to service in the health center compared to respondents who state good employee performance. Thus, it can be concluded that the most dominant variable that has a significant effect on employee loyalty is employee performance after being controlled by service quality and attitude variables. The suggestions from this research are:

1. Health education to patients to change the knowledge, attitudes, and behavior of patients in applying protocol Health during treatment at the health center. Patients must be years, willing, and able to carry out health protocols while in the health center. Patients also need to gain understanding so as not to have to worry excessively in this situation, patients only need to discipline apply protocol health prevention of Covid-19 transmission. As long as the patient is in the health center, the health center needs to provide effective health promotion through media promotion, in the form of leaflets, posters, banners, videos, running text, and so on.

2. The health center needs to maintain the quality of services so that the services provided can provide great benefits for the improvement of public health degrees. Despite the pandemic conditions, people also have the right to quality services, as stated in the 1945 Constitution that every citizen has the right to live a healthy life, and the state guarantees that. The quality of service remains a measure based on services provided to the community.

3. There need to be efforts to maintain good performance in providing health services. It is possible, the health center provides rewards and punishments for employees who perform well and less. Reward and punishment mechanisms can stimulate and maintain the performance of employees. According to researchers, forms of reward and punishment do not have to be material but can be in other forms, for example, additional good holidays of those who perform well, awarding in the form of charters, congratulations, entertainment activities, and other forms.

\section{THANKYOU-NOTE}


1. Allah Almighty for his grace and grace that gives strength to the author so that he can complete this thesis.

2. Prof. Dr. H. Syaiful Bakhri, SH, MH as Rector of Muhammadiyah University of Jakarta

3. Dr. Andriyani, MKes as Dean of the Faculty of Medicine and Public Health, University of Muhammadiyah Jakarta

4. Dr. Dewi Purnawati, SKM, MKM, as Head of Postgraduate Study Program of Muhammadiyah University of Jakarta

5. Dr. dr. Hj. Aragar Putri, MRDM, SPKKLP, as a thesis advisor, has provided direction and guidance in completing this thesis

6. Dr. Andriyani, M.Kes, Dr. Budi Hartono, SE, MARS, ACC and Dr. Irwandy, SKM, Msc.PH, MKes, as examiners for their input on this thesis improvement

7. Wizard Rakha Firdaus Sastya Putra Atmaja

8. Drs.H. Deden Nuruddin, Msc and Hj. Lilih Juliah, both parents

9. Omega DR Year, SKM and Gustomo, SST

\section{REFERENCES}

Adisaputro, Gunawan. 2010. Marketing Management. First edition, Yogyakarta: YKPN College of Management Sciences.

Asif M., Arif Jameel, Abid Hussain, Jinsoo Hwang, and Noman Sahito. Linking Transformational Leadership with Nurse-Assessed Adverse Patient Outcomes and the Quality of Care: Assessing the Role of Job Satisfaction and Structural Empowerment. Int. J. Environ. Res. Public Health 2019, 16, 2381; doi:10.3390/ijerph16132381. Received: 17 June 2019; Accepted: 3 July 2019; Published: 4 July 2019.

Banan, Isma Nurul. 2020. Influence of service quality and trust in patient loyalty at Bumi Panyileukan Health Center bandung. Diploma thesis, UIN Sunan Gunung Djati Bandung.

Dachyar, M., Farizal, \& Minar, I. P. (2018). Patients' Loyalty Improvement in Public Hospital. In MATEC Web of Conferences (Vol. 248). EDP Sciences. https://doi.org/10.1051/matecco $\mathrm{nf} / 201824803015$.

Griffin, (2010). A First Look at Communication Theory.8thedition. Boston: McGraw Hill.Bungin.

Imam Buchari, Bachari Kamal. Mella Sari. The Influence of Service Quality, Company Image, and Satisfaction With Inpatient Loyalty at Mitra Keluarga Tegal Hospital. Journal monex Volume 7 Number 1 January 2018 e-ISSN:2549-5046.

Keshavarz, Yousef, Jamshidi, Dariyoush, and Bakhtazma, Farid. 2016. THE INFLUENCE OF SERVICE QUALITY ON RESTAURANTS' CUSTOMER LOYALTY. Arabian Journal of Business and Management Review (Oman Chapter) Vol. 6, No.4.

Kotler, Philip. 2010. Marketing Management. Thirteen editions Indonesian.Volumes 1 and 2. Jakarta: Erlangga.

Mafalda Lima and Teresa Fernandes. Relationship bonds and customer loyalty: A study across different service contexts. IESS 2015, LNBIP 201, pp. 326-339, 2015.

Linking Transformational Leadership with Nurse Service Outcomes Assessed nurses and Quality of Care: Assessing the Role of Job Satisfaction and Structural Empowerment

Notoatmodjo, Soekidjo. 2010. Health Behavioral Sciences. Jakarta: Rineka Cipta. 
Palit, Kristanti, Aysia, dan Priskila .2016. The Effect of Service Quality and Customer Satisfaction on Customer Loyalty of Small Scale Indonesian Food Enterprises in Surabaya. 4th International Conference on Disciplines in Humanities and Social Sciences (DHSS-2016) Oct. 4-5, 2016 Bali (Indonesia)

Parasuraman, V. A. (2011). A Conceptual Model of Service Quality and Its Implication for Future Research. Service Quality, 2015-220.

Pebrianto Fajar. 2021. Covid-19 Pandemic, JKN Service Visits Dropped Dramatically by 70.69 Million People. https://bisnis.tempo.co/.

Pushkar Dubey, Satish Kumar Sahu. Effect of service quality on perceived value, satisfaction, and loyalty of customers: A study on selected hospitals of Chhattisgarh. International Journal of Computer Sciences and Engineering.

Vol.7, Special Issue.3, Feb. 2019.

Setiawan, Heri dan Sayuti, A. J., 2017. Effects of Service Quality, Customer Trust and Corporate Image on Customer Satisfaction and Loyalty: An Assessment of Travel Agencies Customer in South Sumatra Indonesia. IOSR Journal of Business and Management (IOSR-JBM). e-ISSN: 2278-487X, p-ISSN: 2319-7668. Volume 19, Issue 5. Ver. III (May. 2017), PP 31-40

Selim Ahmed, Kazi Md. Tarique, Ishtiaque Arif. "Service quality, patient satisfaction and loyalty in the Bangladesh healthcare sector", International Journal of Health Care Quality Assurance, Vol. 30 Issue: 5, pp.477-488, 2017.

Taqdees Fatima, Shahab Alam Malik, Asma Shabbir. Hospital healthcare service quality, patient satisfaction, and loyalty: An investigation in the context of private healthcare systems. Volume 35 No. 6, 2018.

Titin Lestariningsih, Ernani Hadiyati, Rini Astuti. Study of Service Quality and Patient Satisfaction to Trust And Loyalty in Public Hospital, Indonesia. International Journal of Business Marketing and Management (IJBMM) Volume 3 Issue 2 February 2018, P.P.01-12 ISSN: 2456-4559 www.ijbmm.com.

Ramli A. Haeba. PATIENT SERVICE AND SATISFACTION SYSTEMS. Business and Entrepreneurial Review: Volume April 2016. ISSN: 0853-9189. Page 189-200.

Wolter, J. S., Bock, D., Smith, J. S., \& Cronin, J. J. (2017). Creating Ultimate Customer Loyalty Through Loyalty Conviction and Customer-Company Identification. Journal of Retailing, 93(4), 458-476. https://doi.org/10.1016/j.jretai.2 017.08.004 